Volume 14(1), 2020

Page: $65-90$

\title{
Psychology of Muslim Investors in Stock Market During COVID-19 Pandemic
}

\author{
Purnama Ramadani Silalahi' ${ }^{1}$, Muhammad Hafizh², Salman Nasution ${ }^{3}$, \\ Sugianto 4
}

\begin{abstract}
The main purpose of this study is to analyze and evaluate the psychology of Muslim investors in stock investments during COVID-19 pandemic. This research uses data collected through online questionnaires conducted in May 2020, and employ Path Analysis to make sense of the data. This study finds that the psychology of Muslim investors investing in stock markets during the COVID-19 pandemic is irrational and intuitive. Muslim investors react quickly without resorting to any fundamental/technical analysis. Muslim investors are willing to take risks and cut losses in this situation. In addition, the psychology of Muslim investors with respect to religiosity is at the second level of Homo Islamicus' self-interest, namely AlNafs Al-Lawamah.
\end{abstract}

Keywords: Psychology of Muslim investors, stock investment, COVID-19

\begin{abstract}
Abstrak. Tujuan utama penelitian ini adalah untuk menganalisis dan mengevaluasi psikologi investor muslim dalam investasi saham pada saat pandemi COVID-19. Penelitian ini menggunakan path analisis. Pengumpulan data dilakukan melalui kuesioner online pada Mei 2020. Studi ini menemukan bahwa psikologi investor Muslim yang berinvestasi di saham selama pandemi COVID-19 tidak rasional dan intuitif. Investor Muslim bereaksi cepat tanpa didasarkan pada analisis fundamental / teknis apa pun. Investor Muslim bersedia mengambil resiko dan melakukan cut loss dalam situasi ini. Selain itu, psikologi investor Muslim dalam aspek religiusitas berada pada level kedua dari kepentingan diri Homo Islamicus yaitu Al-Nafs Al-Lawamah.
\end{abstract}

Kata Kunci: Psikologi investor Muslim, investasi saham, COVID-19

\footnotetext{
${ }^{1}$ Faculty of Islamic Economics and Business, State Islamic University of North Utara | purnamaramadani@uinsu.ac.id

2 Faculty of Islamic Economics and Business, State Islamic University of North Utara | hafizelhabib@gmail.com

${ }^{3}$ Faculty of Islamic Religion, University of Muhammadiyah Sumatera Utara | salmannasution@umsu.ac.id

${ }^{4}$ Faculty of Islamic Economics and Business, State Islamic University of North Utara | sugianto@uinsu.ac.id
} 


\section{Introduction}

Covid-19 pandemic has caused far-reaching changes in various aspects of life, including economic, legal, political, social, educational and others. The spread of corona virus (COVID-19) in various countries is a serious concern for Heads of State across the world. In Indonesia, President Joko Widodo urged the public to implement Physical Distancing and Work From Home (WFH) in order to accelerate the handling of the COVID-19 pandemic. This was supported by Minister of Health Regulation No.9 of 2020 concerning the Guidelines for PSBB. The implementation of Physical Distancing and Work From Home (WFH) certainly makes companies' revenues decrease. The economy and finance of the state have not yet given clear directions and policies (Hafizh et al., 2020). This resulted in a significant decrease in the Jakarta Composite Index, especially in March and April, which caused the movement of the Jakarta Composite Index to be paused for 30 Minutes (Trading Halt) because it had decreased below 5\% in one day. IHSG weakened below the 4000 level which was 3,937 (Citradi, 2020).

This situation provides considerable concern and consideration for investors to invest their capital in the Indonesia Stock Exchange (IDX). This is supported by the statement of former executive of the Indonesia Stock Exchange (BEI), who suggested that the behavior of investors and domestic securities is like 'herds of wild animals' (Agustian, 2009). The behavior of domestic capital market players in Indonesia tends to follow the behavior of others (Septyanto, 2013b). This suggests that Subjective Norm is the basis for stock investment decisions on the Indonesia Stock Exchange (Adhikara et al., 2014; Dihin Septyanto \& Joko, 2016). Subjective norm is the encouragement of others and the environment to take certain actions.

Prospect Theory explains that an investor tends to be influenced by his psychology in risking profits rather than losses. The fall in share prices during the COVID-19 pandemic made investors bolder in risk than profit (Sugianto et 
al., 2020). Components in this theory are regret aversion, loss aversion and mental accounting (Mamun et al., 2015; Nyoman et al., 2017; Sarwar \& Afaf, 2016; Waweru et al., 2008). Psychology includes aspirations, cognitions, emotions, culture, and perception of justice (Shefrin \& Statman, 2011). Meanwhile, Ajzen explained that attitude, Subjective Norm, perceived behavior control influences one's intention to do something (Ajzen, 2005). Adhikara's research includes news, accounting information, unsystematic risk, Subjective Norms, policies, and consideration of investor confidence (Adhikara et al., 2014; Adhikara, Maslichah, 2013). Agustin's research includes religiosity and non-religiosity, which are based on sharia principles (Agustin, 2014).

The phenomenon of significant stock price declines during the COVID19 pandemic caused psychological aspects to play an important role in stock investment decisions. Various studies have been conducted testing the psychological factors that affect stock investment decisions. Paramita et al. found that the psychological aspect directs the irrational behavior of stock investors in biased decision making (Paramitha et al., 2018). Dhaoui et al's research found that investors are more often pessimistic than optimistic in stock transactions (Dhaoui et al., 2013). This will cause the stock price to get out of control. Furthermore, risk perception, loss aversion, herding behavior are also part of investor psychology that influences stock investment decisions (Ahyaruddin et al., 2017; Alquraan, T., Alqisie, A., \& Shofa, 2016; Bakar \& Yi, 2016; Benjamin et al., 2017; Fenny Cathlyn \& Astuti, 2017; Kengatharan, 2019; Khairunizam \& Isbanah, 2019; Pradhana, 2018; Sheikh \& Riaz, 2012).

The fluctuation of stock price movements on the Indonesian stock exchange which is very volatile, this is a serious concern for researchers. Previous studies have focused on investor psychology in various stock exchanges before the existence of the COVID-19 pandemic. This study presents an analysis and description of how Muslim investor psychology invests in the shares of the COVID-19 pandemic. Judging from the Subjective Norm variable, sharia principles, risk, perceived behavior control and stock investment decision. The hypotheses in this study are: 
H1 : Subjective norm affect on the perceived behavior control

H2 : Sharia principles affect on the perceived behavior control

H3 : Risk influences affect on control behavior

H4 : Perceived behavior control affect on stock investment decision

H5 : Subjective norm affect on the stock investment decision

H6 : Sharia principles affect on the stock investment decision

H7 : Risk affect on the stock investment decision

H8 : Subjective norm affect on stock investment decisions through perceived behavior control

H9 : Sharia principles affect on stock investment decisions through perceived behavior control

H10 : Risk affect on the stock investment decision through perceived behavior control

\section{Literature Review}

This theory was put forward by Daniel Kahneman and Amos Tversky (Lubis, 2013). Prospect Theory explains that an investor tends to be influenced by his psychology in risking profits rather than losses. This theory illustrates that an investor will be more determined in taking risks than achieving success (Lubis, 2013). Components in this theory are regret aversion, loss aversion and mental accounting.

Regret Aversion Theory explains how the psychology of an investor regrets for the wrong decisions that have been made. The mistake caused great regret for investors regarding buying and selling at the right time and choosing the right stock he was supposed to do. This regret theory makes a Muslim investor tend to be conservative because he is too antipathic to the economic situation and this will cause investors to eventually change their attitude to herding behavior because he needs the support of others to sell/buy shares at the right time (Michael, 2006) 
Loss Aversion Theory explains the psychology of an investor who feels hurt / sad/disappointed when he suffered a loss greater than feeling happy when he experienced profits even though in the same amount (Tilson, 2005). Illustration, if in a stock portfolio owned by a Muslim investor there are shares TLKM which experienced a potential loss of 10\%, JSMR shares experienced a potential profit of $10 \%$. Then Muslim investors will feel sadder to see his TLKM stock portfolio compared to happy seeing his JSMR shares.

Theory of Mental Accounting explains how investor psychology makes the costs and benefits of a decision he made (Hagstrom, 1999). This situation makes investors tend to think critically about mental accounting that can make a comparison of the benefits he will get compared to the risk he will receive in choosing a share. When the stock price gives a small profit for him, then he is hesitant in acting, but this mental accounting situation can lead investors to be wiser in making stock investment decisions. Illustration, a stock investor will always look at the price movement of a stock and compare the price with PBV and PER of the stock and then compare it with similar stocks and make a calculation of the costs and benefits that he will receive.

Theory of Planned Behavior was put forward by Icek Ajzen, which is based on the assumption that humans are rational creatures who always use information that is available systematically that is influenced by one's conscious intention towards a behavior (Ajzen, 2005). This theory states that attitudes, subjective norms, and behavioral control perceptions together form individual behavioral intentions and behaviors. 1) Attitudes towards behavior, i.e. Positive or negative individual evaluations of certain behavioral performance. 2) Subjective norms, namely individual perceptions of social normative pressures originating from social referrals both friends, analysts and stakeholder policies that support or encourage behavior to make a decision. 3) Perception of behavioral control, namely individual beliefs about the consequences of certain behaviors. This concept is based on subjective probabilities that behavior will produce positive results given (Ajzen, 2005). 


\section{Methods}

This research approach uses a quantitative research approach with survey methods. Data sources use primary data. The population in this study are Muslim investors who are listed as stock investors in Indonesia. Because of the unknown population of Muslim investors listed on the Indonesia Stock Exchange (IDX). The determination of the sample was carried out using the Roscoe method, where the number of variables studied multiplied by a minimum sample of 10 . Then the researchers determined the number of samples of this study by 5 variables multiplied by 25 samples to 125 samples / respondents. This is done to get maximum results from research. Roscoe states, the proper sample size in the study is between 30-500 samples (Sugiyono, 2012). So that the research sample is feasible and represents the population.

Sampling was carried out using purposive sampling technique. The research sample criteria are: 1. Muslim, 2. Investors have stock accounts and 3. Investors have been doing stock transactions for more than 1 year. Data collection techniques by distributing questionnaires via Google forms in May 2020 through online media affiliated with sharia investor groups such as; Whattsapp group, Instagram and Telegram Group. The respondents who filled out this questionnaire were sourced from various provinces in Indonesia, namely North Sumatra, Riau, DKI Jakarta, West Java, Banten, Yogyakarta, West Kalimantan, East Nusa Tenggara, West Nusa Tenggara , Jambi, Central Java, Maluku, Aceh and East Java, South Sulawesi, Lampung. The analysis technique used is Path analysis with analysis tools using SPSS Version 25.

Operational variables are divided into three, namely:

Independent Variable : Subjective Norm, Sharia principles, Risk,

Dependent Variable : Stock investment decision

Intervening Variable : Perceived behavior control 
Subjective norms are investor perceptions of the social referral dimension. Dimensions of social referral are references, references given by the public or related parties in it about a stock. The indicators of this subjective norm are the influence of regulators, friends, mass media and analysts.

Sharia principle in its operation is the fulfilment of sharia values in every sharia financial institution, which refers to the Al-Qur'an and Hadith as its main source. The rules in the provisions contained in both the product, the mechanism, the transaction and the regulations are determined based on the DSN-MUI fatwa (Arifin, 2009). The dimension of sharia principles is sharia compliance. Sharia compliance is the fulfilment of all sharia principles in stock transaction activities.

Risk, in this case, is related to the size of the capital invested by investors. The Risk Dimension adopted in this study is sourced from Adhikara's research; namely, the risk dimension is not systematic. The unsystematic risk dimension is an investor's confidence regarding the financial statement items that are considered to have the potential loss from an outcome (Adhikara et al., 2014).

Perception of behavior control is a view from within an investor in assessing his ability whether he can be able or unable to do something. This view of investor confidence is supported by the knowledge, experience and information that he got from outside. The dimension in this variable is ability. Ability is an assessment or measure of what a Muslim investor can do.

Stock investment decisions in the operations of this study are decisions taken by an investor to take action to sell or buy or to wait and see the situation of stock price movements in the COVID-19 period. Stock investment decisions have a long-term time dimension meaning decisions taken must be considered well because they have long-term consequences also exceed one year (Soetrisno, 2007). This instrument was adopted and developed from Tandelin research (Tandelilin, 2010).

Regression analysis equation the paths of this study are as follows: $\mathrm{Y} 1=p \mathrm{Y}_{1} \mathrm{X}_{1}+\mathrm{pY}_{2} \mathrm{X}_{2}+\mathrm{pY} \mathrm{Y}_{3} \mathrm{X}_{3}+\varepsilon_{1}$ 
$\mathrm{Y} 2=\mathrm{pY}_{2} \mathrm{X}_{1}+\mathrm{pY}_{2} \mathrm{X}_{2}+\mathrm{pY}_{2} \mathrm{X}_{3}++\mathrm{pY}_{2} \mathrm{Y}_{1}+\varepsilon_{2}$

The scheme of this research framework is shown in figure 1.

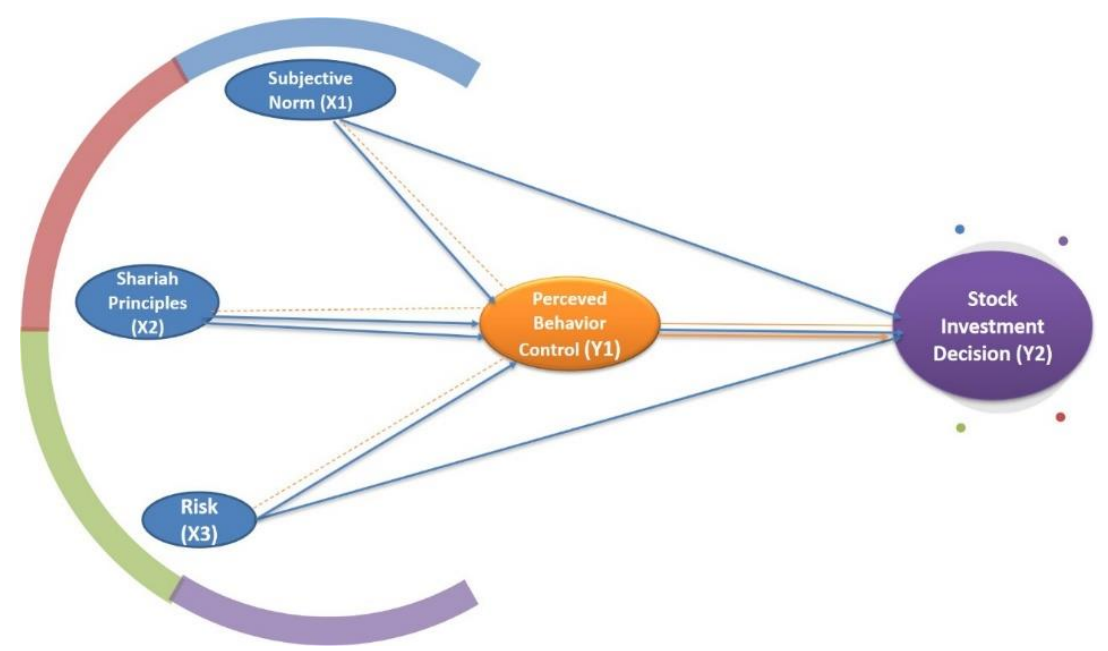

Figure 1. Framework

Note: $\mathrm{X} 1=$ Subjective Norm (NS); $\mathrm{X} 2=$ Sharia principles (PS); X3= Risk (R);

$\mathrm{Y} 1=$ Perceived behavior control (PBC); Y2= Stock investment decision (SID).

\section{Results and Discussions}

Characteristics of research respondents under the heading 'Psychology of Muslim investors in investing stocks during the COVID-19 Pandemic' are summarized in table 1. The respondents are: 1 . Muslim, 2. The investors who have stock accounts and 3. The Investors who have been doing stock transactions for more than 1 year. Table 1 shows that characteristics of respondents in this study meet the criterion of the research that is $100 \%$ Muslim. Roscoe states, the proper sample size in the study is between 30-500 samples (Sugiyono, 2012). So that the research sample is feasible and represents the population. Men dominated the sex of the respondents amounted to 79 people or as much as $63.2 \%$. The work of Muslim Investors is dominated by 54 students or $43.2 \%$. The majority of respondents in this study were millennial investors as many as 86 people or $68.8 \%$ who transacted for more than 1 year. The length of time an investor's stock transactions are dominated millennial investors. 
Table 1. Characteristics of Respondents

\begin{tabular}{lcc}
\hline Religion & Frequency & $\%$ \\
\hline Islam & 125 & $100 \%$ \\
\hline Gender & Frequency & $\%$ \\
\hline Men & 79 & $63.2 \%$ \\
Woman & 46 & $36.8 \%$ \\
\hline Work & Frequency & $\%$ \\
\hline College Student & 54 & $43.2 \%$ \\
PNS & 10 & $8 \%$ \\
Lecturer & 14 & $11.2 \%$ \\
Private & 20 & $16 \%$ \\
Businessman & 8 & $6.4 \%$ \\
Other & 19 & $15.2 \%$ \\
\hline Age & Frequency & $\%$ \\
\hline$<30$ years & 86 & $68.8 \%$ \\
$30-40$ years & 20 & $16 \%$ \\
$40-50$ years & 14 & $11.2 \%$ \\
$>50$ years & 5 & $4 \%$ \\
\hline Old Stock Transaction & Frequency & $\%$ \\
\hline 1-3 years & 104 & $83.2 \%$ \\
3-5 years & 17 & $13.6 \%$ \\
5-7 years & 4 & 3.2 \\
$>7$ years & 0 & 0 \\
\hline
\end{tabular}

Source: Processed research data

Descriptive statistics of variables in the study with the title 'Psychology of Muslim investors in investing stocks during the COVID-19 Pandemic' are presented in table 2 .

Table 2. Descriptive Statistics

\begin{tabular}{lccccc}
\hline \multicolumn{1}{c}{ Variable } & $\mathrm{N}$ & Minimum & Maximum & Mean & $\begin{array}{c}\text { Std. } \\
\text { Deviation }\end{array}$ \\
\hline Subjective Norm & 125 & 4.00 & 20.00 & 15.1280 & 2.97293 \\
Sharia Principles & 125 & 7.00 & 25.00 & 21.5440 & 3.96864 \\
Risk & 125 & 13.00 & 35.00 & 26.5040 & 4.52880 \\
Perceived Behavior Control & 125 & 11.00 & 30.00 & 22.2480 & 3.87435 \\
Stock Investment Decision & 125 & 14.00 & 30.00 & 22.9920 & 3.49769 \\
Valid N (listwise) & 125 & & & & \\
\hline
\end{tabular}

Source: Processed research data

The $\mathrm{R}$ table of this study is the Degree of Freedom $(\mathrm{DF})=\mathrm{N}-2$ where $\mathrm{DF}=125-2=123$ then with a significance of 0.05 , the $\mathrm{r}$ table is 0.1757 . The 
validity test results show that all items of the statement for each variable are declared valid. The reliability test results also showed that all variables were declared reliable because they had a Cronbach Alpha that was greater than 0.600. (see Appendix)

\section{Classical Assumption Test}

The normality test results of this research data can be seen from figure 2 below.

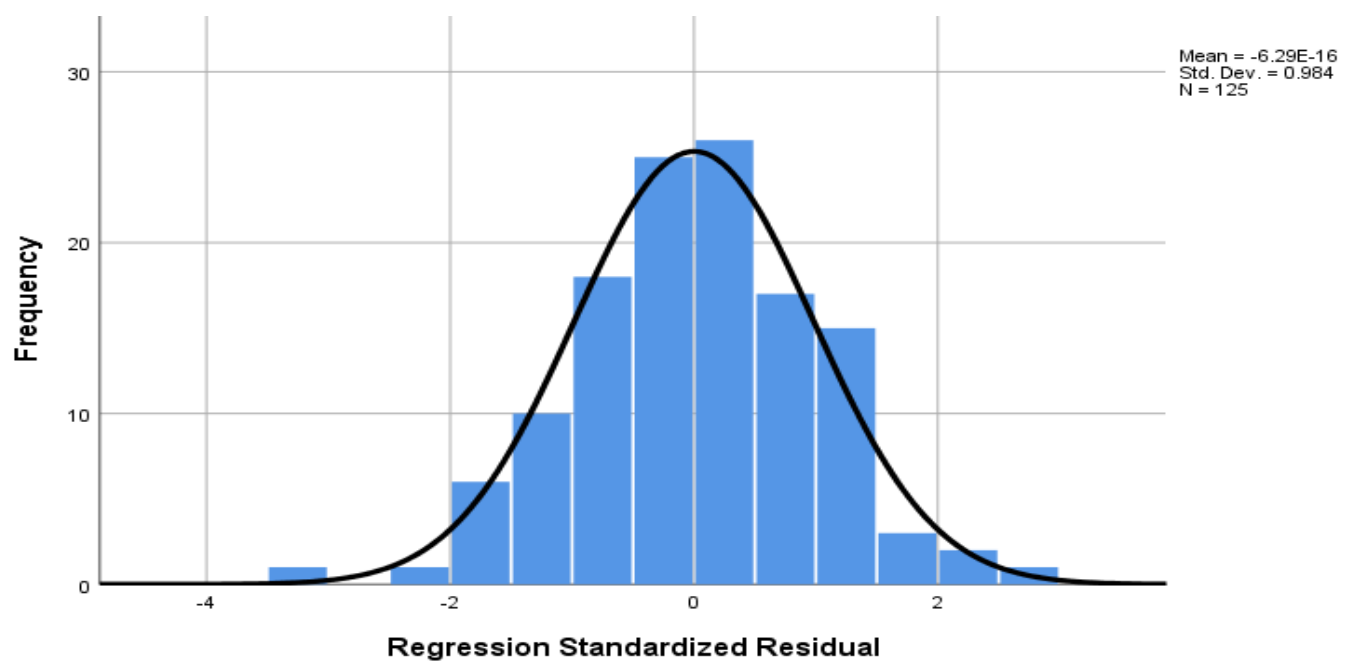

Figure 2. Histogram

Source: Processed research data

The results of the normality test show that all variables are normally distributed; this is because the histogram curve forms a bell or parabolic pattern.

Multicollinearity Test is shown by Tolerance column and column VIF Column. Multicollinearity is not found as Tolerance values are more than 10 percent (Tolerance > 0.01) and the VIF values are less than 10 (VIF < 10).

Table 3. The Multicollinearity Test

\begin{tabular}{lcc}
\hline & \multicolumn{2}{c}{ Collinearity Statistics } \\
Model & Tolerance & VIF \\
\hline $1 \quad$ Constant $)$ & & \\
Subjective Norm & .869 & 1.151 \\
Sharia Principles & .878 & 1.139 \\
Risk & .817 & 1.223
\end{tabular}




\begin{tabular}{lll}
\hline Perceived Behavior Control & .890 & 1.124 \\
\hline A. Dependent Variable: Stock Investment Decision & \\
\hline \multicolumn{2}{c}{ Source: Processed research data }
\end{tabular}

Heteroscedasticity test results show that the data distribution does not show symptoms of heteroskedasticity because the data distribution is spread and does not form a certain pattern.

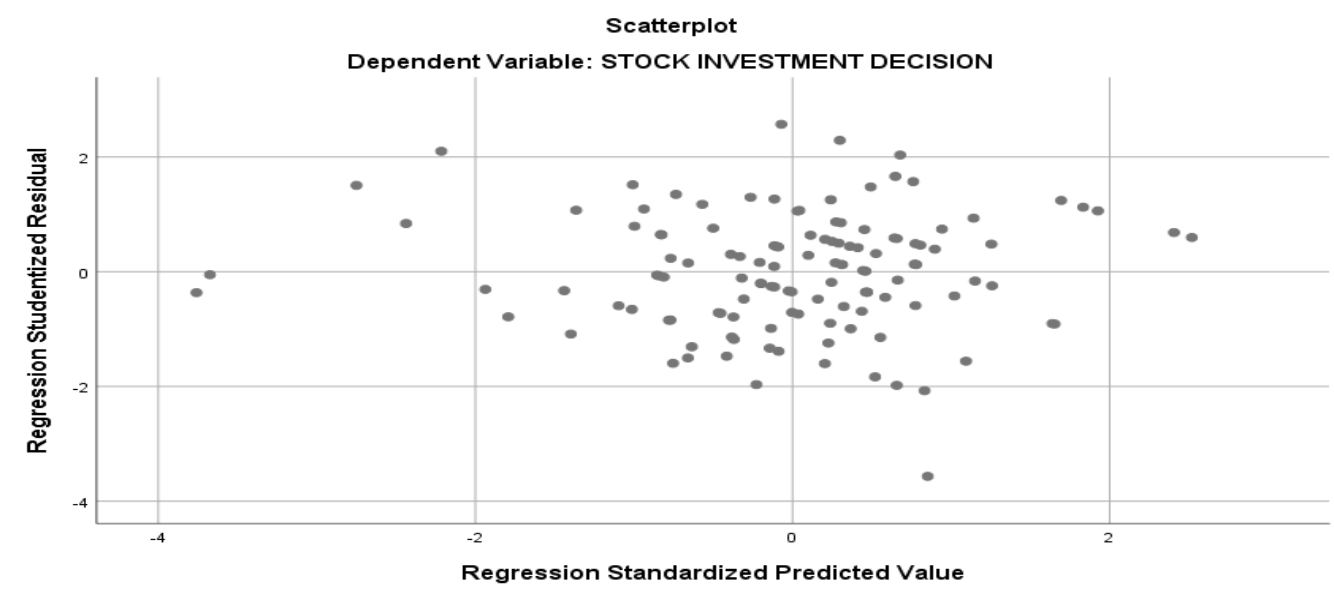

Figure 3. Heteroskedasticity

Source: Processed research data

Model 1

Model I (first) regression analysis was used to determine the strength of the relationship of the independent variable to the mediating variable (intervening). In the regression analysis of model I, the structural equation is:

$$
\mathrm{PBC}=\mathrm{pSN}+\mathrm{pSP}+\mathrm{pR}+\varepsilon 1
$$

Simultaneously, the three subjective norm variables, sharia principles, risk have a probability of 5.004 which means that all four variables together have a significant effect on Perceived Behavior Control at sig $0.003<0.05$. In addition, the magnitude of $\mathrm{R}$ Square is 0.110 or $11.0 \%$ which means Perceived Behavior Control can be explained by the subjective norm, sharia principles, and risk by $11.0 \%$. Other variables explain the rest. (see Appendix) 
Based on the results of the $t$ test, the regression equation that reflects the variables in this study is

$$
P B C=13.241+0.120 S N+0.042 S P+0.237 R+0.943
$$

Table 4. T-Test Results (Equation I)

\begin{tabular}{|c|c|c|c|c|c|c|c|}
\hline \multirow[b]{2}{*}{ Model } & \multicolumn{2}{|c|}{$\begin{array}{l}\text { Unstandardized } \\
\text { Coefficients }\end{array}$} & \multirow{2}{*}{$\begin{array}{c}\begin{array}{c}\text { Standardized } \\
\text { Coefficients }\end{array} \\
\text { Beta }\end{array}$} & \multirow[b]{2}{*}{$\mathrm{T}$} & \multirow[b]{2}{*}{ Sig. } & \multicolumn{2}{|c|}{$\begin{array}{c}\text { Collinearity } \\
\text { Statistics }\end{array}$} \\
\hline & $\mathrm{B}$ & Std. Error & & & & Tolerance & VIF \\
\hline 1 (Constant) & 13.241 & 2.547 & & 5.199 & .000 & & \\
\hline Subjective Norm & .120 & .119 & .092 & 1.008 & .315 & .876 & 1.141 \\
\hline Sharia Principles & .042 & .089 & .043 & .466 & .642 & .879 & 1.137 \\
\hline Risk & .237 & .078 & .277 & 3.034 & .003 & .880 & 1.137 \\
\hline
\end{tabular}

Source: Processed research data

Model II

Model II (second) regression analysis was used to determine the strength of the relationship of the independent variable to the dependent variable. In the regression analysis of model II the structural equation is:

$$
\mathrm{SID}=\mathrm{pSN}+\mathrm{pSP}+\mathrm{pR}+\mathrm{pPBC}+\varepsilon 1
$$

Simultaneously, the four subjective norm variables, sharia principles, risk have a probability of 17,890 , which means the four variables together have a significant effect on Stock Investment Decision at sig 0,000 <0.05. In addition, the results show that the magnitude of $\mathrm{R}$ Square is 0.374 or $37.40 \%$ which means Stock Investment Decision variables can be explained by subjective norm, sharia principles, risk and perceived behavior control by $37.40 \%$.

Table 5. T-Test Results (Equation II)

\begin{tabular}{lcccccccc}
\hline & \multicolumn{2}{c}{$\begin{array}{c}\text { Unstandardized } \\
\text { Coefficients }\end{array}$} & \multicolumn{2}{c}{$\begin{array}{c}\text { Standardized } \\
\text { Coefficients }\end{array}$} & & \multicolumn{3}{c}{$\begin{array}{c}\text { Collinearity } \\
\text { Statistics }\end{array}$} \\
Model & $\mathrm{B}$ & Std. Error & Beta & $\mathrm{T}$ & Sig. & Tolerance & VIF \\
\hline (Constant) & 5.165 & 2.143 & & 2.411 & .017 & & \\
Subjective Norm & .253 & .091 & .215 & 2.779 & .006 & .869 & 1.151 \\
\hline
\end{tabular}




\begin{tabular}{llllllll}
\hline Sharia Principles & .141 & .068 & .160 & 2.076 & .040 & .878 & 1.139 \\
Risk & .211 & .062 & .273 & 3.416 & .001 & .817 & 1.223 \\
Perceived Behavior & .241 & .069 & .267 & 3.487 & .001 & .890 & 1.124
\end{tabular}

Control

A. Dependent Variable: Stock Investment Decision

\section{Source: Processed research data}

Based on the results of the $t$ test, the regression equation that reflects the variables in this study is:

$$
\mathrm{SID}=5.165+0.253 \mathrm{SN}+0.141 \mathrm{SP}+0.211 \mathrm{R}+0.241 \mathrm{PBC}+0.791
$$

Table 6. Results of Analysis of Direct and Indirect Effects

\begin{tabular}{|c|c|c|c|c|c|c|}
\hline Hypothesis & Model & $\begin{array}{c}\text { Standardized } \\
\text { Coefficient } \\
\text { Beta }\end{array}$ & $\mathrm{T}$ & Sig & $\mathrm{R}^{2}$ & Conclusion \\
\hline & \multicolumn{6}{|c|}{ Structural equation $\mathrm{I}\left(\mathrm{X}_{1}, \mathrm{X}_{2}, \mathrm{X}_{3}\right.$ to $\left.\mathrm{Y}_{1}\right)$} \\
\hline $\mathrm{H} 1$ & $\mathrm{X} 1=\mathrm{PX1Y1}$ & 0.120 & 1.008 & 0.315 & & $\begin{array}{l}X_{1} \text { does not } \\
\text { affect } Y_{1}\end{array}$ \\
\hline $\mathrm{H} 2$ & $\mathrm{X} 2=\mathrm{PX} 2 \mathrm{Y} 1$ & 0.042 & 0.466 & 0.642 & 0.110 & $\begin{array}{l}X_{2} \text { does not } \\
\text { affect } Y_{1}\end{array}$ \\
\hline \multirow[t]{2}{*}{$\mathrm{H} 3$} & $\mathrm{X} 3=\mathrm{PX} 3 \mathrm{Y} 1$ & 0.237 & 3.034 & 0.003 & & $X_{3}$ Affect $Y_{1}$ \\
\hline & \multicolumn{6}{|c|}{ Structural equation II $\left(X_{1}, X_{2}, X_{3}, Y_{1}\right.$ ke $\left.Y_{2}\right)$} \\
\hline $\mathrm{H} 4$ & $Y 1=P Y 1 Y 2$ & 0.241 & 3.487 & 0.001 & & $Y_{1}$ Affect $Y_{2}$ \\
\hline H5 & $\mathrm{X} 1=\mathrm{PX} 1 \mathrm{Y} 2$ & 0.253 & 2.779 & 0.006 & & $X_{1}$ Affect $Y_{2}$ \\
\hline H6 & $\mathrm{X} 2=\mathrm{PX} 2 \mathrm{Y} 2$ & 0.141 & 2.076 & 0.040 & 0.374 & $X_{2}$ Affect $Y_{2}$ \\
\hline \multirow[t]{3}{*}{$\mathrm{H} 7$} & $\mathrm{X} 3=\mathrm{PX} 3 \mathrm{Y} 2$ & 0.211 & 3.416 & 0.001 & & $X_{3}$ Affect $Y_{2}$ \\
\hline & \multicolumn{6}{|c|}{ Indirect Affect } \\
\hline & Variable & Direct & Indirect & Total & Criteria & Conclusion \\
\hline $\mathrm{H} 8$ & $\begin{array}{l}\text { Subjective } \\
\text { Norm }\end{array}$ & 0.253 & 0.028 & 0.281 & $\begin{array}{c}\text { Direct } \\
\text { Effect> } \\
\text { Indirect } \\
\text { Effect }\end{array}$ & $\begin{array}{c}Y_{1} \text { is not } \\
\text { intervening } \\
\text { variable }\end{array}$ \\
\hline H9 & $\begin{array}{l}\text { Sharia } \\
\text { Principles }\end{array}$ & 0.141 & 0.010 & 0.151 & $\begin{array}{c}\text { Direct } \\
\text { Effect> } \\
\text { Indirect } \\
\text { Effect }\end{array}$ & $\begin{array}{c}\mathrm{Y}_{1} \text { is not } \\
\text { intervening } \\
\text { variable }\end{array}$ \\
\hline H10 & Risk & 0.211 & 0.057 & 0.268 & $\begin{array}{c}\text { Direct } \\
\text { Effect> } \\
\text { Indirect } \\
\text { Effect }\end{array}$ & $\begin{array}{c}Y_{1} \text { is not } \\
\text { intervening } \\
\text { variable }\end{array}$ \\
\hline
\end{tabular}

Effect of subjective norm (X1) on perceived behavior control (Y1)

This study found that subjective norm does not affect perceived behavior control. Significance value was obtained for $0.315>0.05$ and $t$-count is smaller than $\mathrm{t}$-table $(1.008<1.675)$, then the conclusion is that $\mathrm{H} 0$ is accepted 
and $\mathrm{Ha}$ is rejected. In the theory of planned behavior, Subjective Norm is a social reference given by friends, analysts, policy makers (OJK and BEI) as well as the environment which is used as a social reference in consideration of Muslim investor confidence in valuing a stock. The situation of IHSG price movements during the COVID-19 period experienced a significant decline, especially in March and April, which caused the movement of the IHSG to be paused for 30 Minutes (Trading Halt) because it had decreased below 5\% in one day. The existence of Trading Halt makes Muslim investor psychology out of control. This makes the policies of stakeholders such as OJK, the Indonesia Stock Exchange not be taken into consideration for Muslim investors. The difference in the findings was caused by the condition of the capital market during the Covid-19 pandemic that could not be controlled properly. This was based on the findings of the inability of Muslim investors to control their perceptions in valuing a stock. This result is different from the conducted by Ilham Masrurun (2015), where subjective norm affect perceived behavior control. (Yanto, 2015).

\section{Effect of sharia principles (X2) on perceived behavior control (Y1)}

This study found that the sharia principles does not affect perceived behavior control. Significance value obtained was $0.642>0.05$ and t-count was smaller than t-table $(0.466<1.675)$, then the conclusion was that $\mathrm{H} 0$ was accepted and Ha was rejected. Spiritual morality of Muslims at least forms the basis of sharia compliance for their beliefs in terms of determining investment decisions they do. As Muslims, of course the behavior and attitude of a Muslim investor is inseparable from the teachings of Islam. Muslims in investing in shares should have the attitude of Homo Islamicus. Homo islamicus is an attitude that distinguishes Muslims from other people by making God as the main goal in every action and will be held accountable by Allah SWT.

In this study, sharia principles in the investment activities of a Muslim investor include at least 5 indicators namely: 1) Does not contain usury, 2) Does 
not contain gharar, 3) Does not contain maysir, 4) Avoids haram, 5) Avoids the element of doubt. This study is in line with the research of Sugianto (2020) and Agustin (2014) who found that Muslim investors often ignore sharia principles as a basis for consideration of their decisions (Agustin, 2014; Sugianto et al., 2020). The behavior of Muslim investors is divided into 2 namely investors who consider religion and ones not considering religion. For investors who are considering religion in transaction behavior stocks prefer stocks ones entered in the list of sharia index, fine index JII and ISSI and growing with the long term. While the behavior of Muslim investors who don't consider having religion mix stock composition and properties the investment is short term.

Effect of risk (X3) on perceived behavior control (Y1)

This study found that risk affect perceived behavior control. Significance value obtained was $0.003<0.05$ and t-count were greater than $t$ table $(3.034>1.675)$, then the conclusion was that $\mathrm{H} 0$ was rejected and Ha was accepted. Muslim investors dare to take risks if he believes the investment he will do will get a greater return than the risk he receives. And vice versa, Muslim investors dare to make a loss if he feels the stock he has will experience a large loss. As a study conducted by Roth in 2007 which explained that investors would feel more hurt if they experience loss (loss) rather than getting a gain (profit) in the same amount this is often referred to as loss aversion (Roth, 2007). Loss aversion is one of the behavioral economic concepts in the form of a person's judgment to avoid losses because they know that the pain of loss is greater than the satisfaction of getting an opportunity/profit equal or more. This result is support by research conducted by Septyanto and Adhikara (2013). In terms of responding risk, investors are risk averter. this is done by investors to match their stock portfolios (Septyanto, 2013a).

Effect of perceived behavior control (Y1) on stock investment decision (Y2)

This study found that perceived behavior control affect stock investment decision. The significance value obtained is $0.001<0.05$ and t-test is 
greater than t-table (3.487> 1.657), then the conclusion is $\mathrm{H} 0$ is rejected and $\mathrm{Ha}$ is accepted. Commerce behavior behavior is a perception of the strength of factors that make it easier or harder for investors do a behavior. Stock investment decisions do not always behave in ways that are consistent with assumptions made according to the understanding of the information received. But it can also be influenced by psychological factors that exist in him and his confidence in taking a stock investment decision. Based on research conducted by Magdalena and Susanti, emotions can influence an investor's decision in making investment decisions (Magdalena \& Susanti, 2015). When emotions are bad (bad mood) as a result, investor behavior becomes unstable and can make wrong investment decisions and vice versa, when investor behavior is stable (good mood), investors can make investment decisions properly and correctly. Based on research conducted can it is classified that Muslim investors in the pandemic COVID-19 era belong to the type of intuitive investor, the type of investor who makes decisions based on instinct and tends to act based on feelings.

Effect of subjective norm (X1) on stock investment decision (Y2)

This research found that subjective norm effect on stock investment decision. The significance value obtained was $0.006<0.05$ and $t$-count was greater than $\mathrm{t}$-table $(2.779>1.657)$, then the conclusion was that $\mathrm{H} 0$ was rejected and Ha was accepted. According to Azjen, in the theory of planned behavior, the more trusting Muslim investors with regard to social referrals, the Muslim investors will tend to take action to shape their behavior, the more trusting Muslim investors are about these obstacles then he will undo his intentions and not take any action (Ajzen, 2005). In this case, stock investors are emotionally out of control. The existence of selling action in almost all sectors of the stock makes Muslim investors also become followers of the behavior of others without looking at or considering whether what they are doing is right or wrong. In terms of responding to social referrals both sourced from friends, stock analysts, regulators and mass media (Dhaoui et al., 2013; Untari, 2017). 
This is in accordance with research conducted by Adhikara (2014) the result of her research show that the subjective norms and revisions belief as the basis for taking share decisions (Adhikara et al., 2014). Facts in the field, based on CNN news informs that the shares of PT Mitra Keluarga Kary Advisor tbk (MIKA) fell 5.2\%. after reporting that there were two patients in the hospital who were positive for corona / COVID-19. this happens because of investor anxiety that is not based on accurate analysis (CNN Indonesia, 2020).

Effect of sharia principles (X2) on stock investment decisions (Y2)

This research found that the sharia principles affect the stock investment decision. The significance value obtained was $0.040<0.05$ and the $t-$ test was greater than t-table $(2.076>1.657)$, so the conclusion was that $\mathrm{H} 0$ was rejected and Ha was accepted. The rationality of Muslim investors is based on the spirituality of Islamic values inherent in him as a form of servitude to Allah SWT. So that the fluctuations in stock prices that are not in accordance with the market price are not merely caused by the following-up situation of Muslim investors in investing in the pandemic COVID-19. When it should be combined with the beliefs and obedience of the teachings of religious norms inherent in Muslim investors. This is supported by research Metwally (1985) in his research journal entitled 'The Role of the Stock Exchange in an Islamic Economy' which explains that behavioral behavior in the stock market aims to eliminate uncertain stock price movements by: 1. Prohibiting speculation, 2. Only allows cash purchases, and 3. Eliminating management malpractice (Metwally, 1985).

Effect of risk (X3) on stock investment decisions (Y2)

This research found that risk has effect on stock investment decision. Significant value obtained by $0.001<0.05$ and $\mathrm{t}$-test is greater than $\mathrm{t}$-table (3.416> 1.657), then the conclusion is that $\mathrm{H} 0$ is rejected and Ha is accepted. In modern investment decision making, knowing one's risk tolerance is very important in developing financial plans and investments in addition to knowing one's financial goals, time horizons, and stability. The important role 
of estimating financial risk tolerance for investors and financial planners is to reduce reactions to market fluctuations. From the type of investor seen from his willingness to bear investment risk, Muslim investors in this study are included in the type of risk averter investor. Risk averters are investors who do not like risk or avoid risk. This type of investor will avoid a large risk and divert investment in low risk stocks. So investors often make a loss if he believes that the shares he has can experience a deeper decline. This is in line with Tandelilin which says that one of the basic investment decisions is risk (Marsis, 2013; Tandelilin, 2010).

Effect of Subjective Norm (X1) on stock investment decisions (Y2) through perceived behavior control (Y1)

This study found that subjective norm does not affect stock investment decisions through perceived behavior control. This can be seen from the direct effect is greater than the indirect effect $(0.253>0.028)$, the conclusion is that $\mathrm{H} 0$ is accepted and Ha is rejected. This means that Muslim investors do not make recommendations from friends, mass media, stock analysts as a basis for consideration for investors in providing support for their behavior. This can be due to the fact that investors will consider aspects other than subjective norms in making stock investment decisions. In online news Kontan (2020) and CNBC Indonesia (2020) provides news about sluggish sales from the property sector so that many stock investors sell shares in the property sector they own at that time. This causes the property sector's share price to decline (Kontan.co.id, 2020; Sidik, 2020). In this case, a Muslim investor does not necessarily sell shares in his property sector, this could be because Muslim investors still think this weakening is only temporary. This is supported by Sugianto's research (2020) which found that subjective norm does not affect stock investment decisions through perceived behavior control.

Effect of sharia principles (X2) on stock investment decisions (Y2) through perceived behavior control (Y1) 
This study found that the sharia principles does not affect stock investment decisions through perceived behavior control. This can be seen from the direct effect is greater than the indirect effect $(0.141>0.010)$, then the conclusion is that $\mathrm{HO}$ is accepted and $\mathrm{Ha}$ is rejected. The behavior of Muslim investors who do not make sharia compliance the basis for their investment decisions is generally caused by a number of factors such as the lack of investor knowledge regarding the provisions of the sharia stock category, movement of sharia stocks, which in this case is seen from the movements of ISSI, JII and JII 70 which seem stagnant compared with the movement of the IHSG, and the lack of familiarity of Islamic stocks among Muslim investors. So it is important to educate investors especially those who are Muslim to find out the Sharia Securities List category. However, the revision, evaluation and improvement for Muslim investors requires increased awareness and respect towards higher self-interest, namely al-Nafs al-Muthmainnah which discusses Islamic law and spiritual morals that are not related to servitude to Allah SWT. Then this will bring a Muslim investor to reach falah, namely the happiness of the world and the hereafter. Homo Economicus with common stock investors as Homo Economicus.

Effect of risk (X3) on stock investment decisions (Y2) through perceived behavior control (Y1)

This study found that risk does not affect the stock investment decision through the perception of behavioral control. This is seen from the direct effect is greater than the indirect effect $(0.211>0.057)$, then the conclusion is that $\mathrm{H} 0$ is accepted and Ha is rejected. This means that indirectly, risk does not affect the stock investment decision making through individual perceived control behavior because Muslim investors often react quickly to a risk, but this does not rule out the possibility of other subjectivity considerations or other psychological factors that are more dominant will influence the decision of Muslim investors in making decisions without considering the risks that will be borne in the future. Investor risk tolerance is not static and can change from 
time to time (Koonce, 2004; Sarwar \& Afaf, 2016). When psychological and economic factors change, its position in the risk-return spectrum also changes. Risk tolerance is an investment principle that is difficult to understand and is a complex concept (Benjamin et al., 2017; Nofsinger, 2005). Every investor has different risk tolerance and his attitude towards risk is also different. Types of investors based on their willingness to manage risk: 1. Risk seekers, namely investors who are able to take risks, 2. Risk averters, namely investors who are unable to take risks, 3. Moderate risk, namely investors who are neutral towards risk (Lubis, 2013)

\section{Conclusion}

Indonesia's economic and financial conditions during the COVID-19 pandemic are unstable and difficult to control. This condition has an impact on the psychology of Muslim investors. Muslim investors find it difficult to filter information and control themselves in valuing the right stocks. The psychology of Muslim investors investing in stocks during the COVID-19 pandemic is irrational and intuitive. Muslim investors react quickly without being based on any fundamental / technical analysis.

This result is based on the findings that first, subjective norms and Islamic principles have no effect on perceptions of behavior control. Risk affects perceptions of behavioral control. Second, perceptions of behavioral control, subjective norms, sharia principles and risks affect stock investment decisions. Third, subjective norms, principles and Islamic risk do not affect the perception of behavior control investment decisions. Muslim investors are willing to take risks and cut losses in this situation. Muslim investors responded negatively to the movement of shares on the IDX. Panic selling resulted in a trade cessation policy by the OJK and the IDX. Investors ignore the financial information that the company releases every quarter and semester. This is due to panic by Muslim investors seeing the rapid spread and increase of positive patients with COVID-19, lock-down Policy, Work From Home and physical distancing. However, the psychology of Muslim investors in the aspect of religiosity is at 
the second level of Homo Islamicus' self-interest, namely Al-Nafs Al-Lawamah. Al Nafs Al-Lawamah is characterized by the emergence of intuitive awareness and sharia principles.

Next research can add relevant variables and research with different methods. Thank you to all parties and respondents who contributed to the completion of this scientific article. Hopefully, this scientific article will benefit readers. The research sample is dominated by students who are still learning to invest in stocks. The majority of Muslim investors are millennial investors so they tend to have unstable and inexperienced emotional stability. It is hoped that further research can take a sample of more experienced investors and increase the number of variables relevant to the research.

\section{References}

Adhikara, A., Masclichah \& Nurdiana. (2014). Manfaat Informasi Akuntansi Terhadap Intensi Pemilihan Saham di Bursa Efek Indonesia. Simposium Nasional Akuntansi XVII.

Agustian, W. (2009). Perilaku Investor Domestic Cenderung Ikut Pemain Asing. Retrieved from : Https:// Economy.Okezone.Com, 1.

Agustin, P. (2014). Perilaku Investor Muslim dalam Bertransaksi Saham di Pasar Modal. JESTT, Vol. 1(12): 888-891.

Ahyaruddin, M., Widiarsih, D., \& Winarso, D. (2017). The Effect of Investor Psycology on Trading Volume. Jurnal Akuntansi \& Ekonomica, Vol. 7(2): 122-130.

Ajzen, I. (2005). Theory of Planned Behavior. Organizational Human Behavior and Human Decission Processes.

Alquraan, T., Alqisie, A., \& Shofa, A. A. (2016). Do Behavioral Finance Factors Influence Stock Investment Decisions of Individual Investors? ( Evidences from Saudi Stock Market ). American International Journal of Contemporary Research, Vol. 6(3): 159-169.

Arifin, Z. (2009). Dasar-dasar Manajemen Bank Syariah. In Aztera Publizer. Aztera Publizer.

Arrozi, M. F., \& Maslichah, N. D. (2013). Karakteristik Kualitatif Informasi dalam Revisian Keyakinan Pengguna untuk Penilaian Prospek Sekuritas di Bursa Efek Indonesia (BEI). 16. http:// pdeb.fe.ui.ac.id/?p=5345

Bakar, S., \& Yi, A. N. C. (2016). The Impact of Psychological Factors on Investors' Decision Making in Malaysian Stock Market: A Case of 
Klang Valley and Pahang. Procedia Economics and Finance, Vol. 35(October 2015): 319-328. https://doi.org/10.1016/s22125671(16)00040-x

Benjamin, J., Duarte, D., Hernán, L., \& Sarmiento, T. (2017). Evaluation of The Effect of Investor Psychology on an Artificial Stock Market Through its Degree of Efficiency. Contaduría y Administración, Vol. 62(4): 13611376. https:// doi.org/10.1016/j.cya.2017.06.014

Cathlyn, F., \& Astuti, D. (2017). Pengaruh Financian Literacy dan Financial Psycology Terhadap Investment Decision Professional Muda di Surabaya. Manajemen Keuangan, Vol. 5(1).

Citradi, T. (2020). “Kebakaran” Lagi, IHSG Kena Trading Halt \& Keluar dari 4000. www.cnbcindonesia.com, 1. Retrieved from : https://www.cnbcindonesia.com/market/20200323144916-17146992/ kebakaran-lagi-ihsg-kena-trading-halt-keluar-dari-4000

CNN Indonesia. (2020). Sentimen Virus Corona, Saham Mitra Keluarga Jatuh 5,2 Persen. Retrieved from : https://M.Cnnindonesia.Com, 1.

Dhaoui, Bourouis, \& Boyaciouglu. (2013). The Impact of Investor Psychology on Stock Market: Evidence From France. Journal of Academic Research in Economics, Vol. 5(1).

Hafizh, M., Hidayah, N., \& Silalahi, P. R. (2020). Macroeconomic and Profit Sharing Financing in Islamic Banking in Indonesia: The Third Parties Fund As Intervening. Jurnal Akuntansi Dan Keuangan Islam, Vol. 8(2).

Hagstrom, R. G. (1999). The Warren Buffett Portfolio Mastering the Power of the Focus Investment Strategy. John Wiley \& Sons, Inc.

Halim, V. (n.d.). Beaking News: IHSG Kena Trading Halt Lagi, Perdagangan Saham Distop. Okezone.Com, 1. Retrieved from : https://economy.okezone.com/read/2020/03/17/278/2184699/bre aking-news-ihsg-kena-trading-halt-lagi-perdagangan-saham-distop

Kengatharan, L. (2019). Factors Influencing Investment Decision in Stock Market: Evidence from Individual Investors in The Northern Province of Sri Lanka. 1st Asia Pacific Symposium on Academic Research (APSAR-2019).

Khairunizam, \& Isbanah, Y. (2019). Pengaruh Financial Literacy dan Behavioral Finance Factors Terhadap Keputusan Investasi. Jurnal Ilmu Manajemen, Vol. 7(2): 516-528.

Kontan.co.id, A. (2020, November). Saham LPKR ditutup Turun 1,78\% di Harga Rp 166 pada Kamis 26/11. Pusatdata.Kontan.Co.Id.

Koonce. (2004). Using Psychology Theories in Archival Financial Accounting Research. Journal of Accounting Literature.

Lubis, A. N. (2013). Perilaku Investor Keuangan. USU Press. 
Magdalena, B., \& Susanti. (2015). Perilaku Wanita dalam Berinvestasi di Bandar Lampung. Jurnal Manajemen Dan Bisnis, Vol. 5(2): 217-241.

Maharani, T. (n.d.). Jubir Pemerintah: Penerapan Physical Distancing Diperkuat Melalui Kebijakan PSBB. Compas.Com, 1. Retrieved from : https://nasional.kompas.com/read/2020/04/10/18195851/jubirpemerintah-penerapan-physical-distancing-diperkuat-melaluikebijakan

Mamun, A., Syeed, A., \& Yasmeen, F. (2015). Journal of Economic E Financial Studies Are Investors Rational, Irrational or Normal ?, Vol. 3(04): 1-15.

Marsis, A. S. (2013). Rahasia Terbesar Invesasi. Second Hope.

Metwally, M. M. (1985). The Role of the Stock Exchange in an Islamic Economy, Vol. 3(1): 75-81.

Michael, P. (2006). Behavioral Finance and Wealth Management. John Wiley and Son Inc.

Nofsinger, J. (2005). Psychology of Investing. Precentice-Hall Inc.

Nyoman, N., et al. (2017). Modal Investasi Awal Dan Persepsi Risiko. Jurnal Ilmiah Akuntansi, Vol. 2(2): 173-190.

Paramitha, T., Kusumaningrum, T. M., Mushodhalifah, M., \& Hartono, U. (2018). Young Investor Behavior: Implementation Theory of Planned Behavior. International JOurnal of Civil Engineering and Technology, Vol. 9(7): 733-746.

Perwitasari, A. S. (n.d.). IHSG Kena Trading Halt lagi pada Kamis (19/3) Pukul 09.03 WIB. Kontan.Co.Id, $1 . \quad$ Retrieved from : https:/ / investasi.kontan.co.id/news/ihsg-kena-trading-halt-lagipada-kamis-193-pukul-0937-wib

Pradhana, R. (2018). Pengaruh Financial Literacy, Cognitive Bias, Dan Emotional Bias Terhadap Keputusan Investasi (Studi Pada Investor Galeri Investasi Universitas Negeri Surabaya). Jurnal Ilmu Manajemen, Vol. 6(3): 108-117.

Roth, A. (2007). Behavior Finance. Article Wealth Logic, LLC.

Sarwar, A., \& Afaf, G. (2016). A Comparison Between Psychological and Economic Factors Affecting Individual Investor' S Decision- Making Behavior. Cogent Business \& Management, Vol. 5. https://doi.org/10.1080/23311975.2016.1232907

Septyanto, D. (2013a). Faktor-faktor yang Mempengaruhi Investor Individu dalam Pengambilan Keputusan Investasi Sekuritas di Bursa Efek Indonesia (BEI). Ekonomi, Vol. 4 N(Investasi).

Septyanto, D. (2013b). Perilaku Investor Individu dalam Pengambilan Keputusan Investasi Sekuritas di Bursa Efek Indonesia. Sustainable Competitive Advantage (SCA). 
Septyanto, D., Sudarwan, \& Joko, I. (2016). Model Perilaku Syariah dalam Pengambilan Keputusan Investasi Pada Investor Muslim di Bursa Efek Indonesia. Prodi Manajemen Fakultas Ekonomi Dan Bisnis Universitas Jember.

Shefrin, H., \& Statman, M. (2011). Behavioral Finance in the Financial Crisis: Market Efficiency, Minsky, and Keynes. 53. Retrieved from : https:/ / www.russellsage.org/sites/all/files/RethinkingFinance/Shefrin Statman 01272012.pdf

Sheikh, M. ., \& Riaz, K. (2012). Overconfidence Bias, Trading Volume and Returns Volatility: Evidence from Pakistan. World Applied Science Journal, Vol. 18(12): 1737-1748.

Sidik, S. (2020, July). Gegara Corona, Lippo Karawaci \& Agung Podomoro Catat Rugi. CNBC Indonesia.

Soetrisno. (2007). Manajemen Keuangan Teori Konsep dan Aplikasi. Ekonisia.

Sugianto, et al. (2020). The Behavior of Muslim Investors in Investing in Stocks on The Indonesia Stock Exchange during The Covid-19 Pandemic. Systematic Reviews in Pharmacy, Vol. 11(4): 745-752. https://doi.org/10.31838/srp.2020.4.109

Sugiyono. (2012). Metode Penelitian: Kuantitatif, Kualitatif dan RED. Alfabeta.

Supriadi, E. (2014). SPSS+Amos. In Media.

Tandelilin, E. (2010). Portofolio dan Investasi: Teori dan Aplikasi. Kanisius.

Tilson, W. (2005, November). Appliying Behavioral Finance to Value Investing. T2 Partners LLC. www.T2PartnersLLC.com

Untari, M. D. A. (2017). The Influence Of Follower Investor Behaviour to The Stock of Volatility. Jurnal Ilmiah Akuntansi dan Bisnis, Vol. 12(1): 44-53. https://ojs.unud.ac.id/index.php/jiab/article/view/25857/17842

Waweru, N. M., Munyoki, E., \& Uliana, E. O. (2008). The Effects of Behavioral Factors in Investment Decision-Making: A Survey of Institutional Investors Operating at The Nairobi Stock Exchange. International Journal of Business and Emerging Markets: 24-41.

Yanto, I. M. dan H. (2015). Determinan Perilaku Investor Individu dalam Pengambilan Keputusan Investasi Saham. Accounting Analysis Journal, Vol. 4(4): 1-9.

\section{Appendices}

Appendix 1. The Reliability Test

\begin{tabular}{cccc}
\hline Variable & Cronbach's Alpha & Koesfisien Alpha & Note \\
\hline Subjective Norm & 0.674 & 0.600 & Reliable \\
Sharia Principles & 0.901 & 0.600 & Reliable
\end{tabular}


TIFBR | Tazkia Islamic Finance and Business Review

Volume 14(1), 2020

\begin{tabular}{llll} 
Risk & 0.812 & 0.600 & Reliable \\
Perceived Behavior Control & 0.745 & 0.600 & Reliable \\
Stock Investment Decision & 0.685 & 0.600 & Reliable \\
\hline
\end{tabular}

Source: Processed research data

Appendix 2. The Validity Test

\begin{tabular}{|c|c|c|c|c|}
\hline Variable & Indicator & R Count & R Table & Note \\
\hline \multirow[t]{4}{*}{ Subjective Norm } & SN1 & 0.752 & 0.1757 & Valid \\
\hline & SN2 & 0.648 & & \\
\hline & SN3 & 0.796 & & \\
\hline & SN4 & 0.682 & & \\
\hline \multirow[t]{5}{*}{ Sharia Principles } & SP1 & 0.881 & 0.1757 & Valid \\
\hline & SP2 & 0.734 & & \\
\hline & SP3 & 0.856 & & \\
\hline & SP4 & 0.884 & & \\
\hline & SP5 & 0.882 & & \\
\hline \multirow[t]{7}{*}{ Risk } & R1 & 0.773 & 0.1757 & Valid \\
\hline & $\mathrm{R} 2$ & 0.680 & & \\
\hline & R3 & 0.686 & & \\
\hline & R4 & 0.579 & & \\
\hline & R5 & 0.761 & & \\
\hline & R6 & 0.664 & & \\
\hline & R7 & 0.742 & & \\
\hline \multirow[t]{6}{*}{ Perceived Behavior Control } & PBC1 & 0.711 & 0.1757 & Valid \\
\hline & РBC2 & 0.445 & & \\
\hline & PBC3 & 0.683 & & \\
\hline & PBC4 & 0.761 & & \\
\hline & PBC5 & 0.730 & & \\
\hline & РBC6 & 0.679 & & \\
\hline \multirow[t]{6}{*}{ Stock Investment Decision } & SID1 & 0.710 & 0.1757 & Valid \\
\hline & SID2 & 0.692 & & \\
\hline & SID3 & 0.669 & & \\
\hline & SID4 & 0.650 & & \\
\hline & SID5 & 0.668 & & \\
\hline & SID6 & 0.397 & & \\
\hline
\end{tabular}

Source: Processed research data 
Appendix 3. F Test Results (Equation I)

ANOVA

\begin{tabular}{lrrrrr}
\hline Model & Sum of Squares & Df & Mean Square & F & \multicolumn{1}{c}{ Sig. } \\
\hline 1 Regression & 205.433 & 3 & 68.478 & 5.004 & $.003^{\mathrm{b}}$ \\
Residual & 1655.879 & 121 & 13.685 & & \\
Total & 1861.312 & 124 & & & \\
\hline
\end{tabular}

A. Dependent Variable: Perceived Behavior Control

B. Predictors: (Constant), Risk, Sharia Principles, Subjective Norm

Appendix 4. R2 Test Results (Equation I)

Model Summaryb

\begin{tabular}{|c|c|c|c|c|c|c|}
\hline \multicolumn{7}{|c|}{ Model summary } \\
\hline Model & $\mathrm{R}$ & & R Square & $\begin{array}{l}\text { Adjusted R } \\
\text { Square }\end{array}$ & $\begin{array}{l}\text { Std. Error Of } \\
\text { The Estimate }\end{array}$ & Durbin-Watson \\
\hline 1 & & $.332^{\mathrm{a}}$ & .110 & .088 & 3.69932 & 1.92 \\
\hline
\end{tabular}

A. Predictors: (Constant), Risk, Sharia Principles, Subjective Norm

B. Dependent Variable: Perceived Behavior Control

Source: Processed research data

Appendix 5. F Test Results (Equation II)

\begin{tabular}{|c|c|c|c|c|c|}
\hline Model & Sum of Squares & Df & Mean Square & $\mathrm{F}$ & Sig. \\
\hline 1 Regression & 566.694 & 4 & 141.674 & 17.890 & $.000^{\mathrm{b}}$ \\
\hline Residual & 950.298 & 120 & 7.919 & & \\
\hline Total & 1516.992 & 124 & & & \\
\hline
\end{tabular}

A. Dependent Variable: Stock Investment Decision

B. Predictors: (Constant), Perceived Behavior Control, Sharia Principles, Subjective Norm, Risk

Source: Processed research data

Appendix 6. R² Test Results (Equation II)

\begin{tabular}{l|c|c|c|r|r}
\hline Model & $\mathrm{R}$ & $\mathrm{R}$ Square & Adjusted R Square & Std. Error of the Estimate & Durbin-Watson \\
\hline 1 & $.611^{\mathrm{a}}$ & .374 & .353 & 2.81410 & 1.767 \\
\hline \multicolumn{7}{l}{ A. Predictors: (Constant), Perceived Behavior Control, Sharia Principles, Subjective Norm, Risk } \\
\hline
\end{tabular}

Source: Processed research data 